\title{
THE VIEW OF MAYA CAVE RITUAL FROM THE OVERLOOK ROCKSHELTER, CAVES BRANCH RIVER VALLEY, CENTRAL BELIZE
}

\author{
Gabriel D. Wrobel ${ }^{1}$, Rebecca Shelton², Shawn Morton ${ }^{3}$, Joshua Lynch ${ }^{4}$, And Christopher Andres 5
}

\begin{abstract}
Archaeological investigations of the Overlook Rockshelter in the Caves Branch River Valley of central Belize offer a unique view of ancient Maya cave ritual through the complete recovery and analysis of all artifacts within the site's two small activity areas. In general, the assemblage contains many of the same types of objects documented from other nearby caves and rockshelters. However, the nearly 1700 ceramics sherds showed almost no refits, demonstrating that sherds were deposited at the site individually, rather than as complete vessels. The human bone assemblage represents three or four individuals, with the majority of the bones comprising a single individual, and all of these were deposited as incomplete secondary interments. Analogies for this depositional behavior based on archaeological and ethnographic studies suggest that this rockshelter may represent a waypoint within a ritual circuit composed of multiple locations over which fragments of complete items such as ceramic vessels and secondary burials were spread.
\end{abstract}

\section{INTRODUCTION}

Maya cave archaeology has gained much momentum within the last two decades, supplementing traditional archaeological approaches by expanding discussions of the roles of ideology and ritual within Maya sociopolitical structure. While ethnographic and ethnohistoric studies link caves, rockshelters, and sinkholes to rain and fertility rituals, iconographic and archaeological data from precontact contexts often demonstrate the further use of these natural features in rites of political accession, aggrandizement, legitimization, and social incorporation (BassieSweet, 1996; Prufer and Brady, 2005; Vogt and Stuart, 2005). Thus, an important aspect of Maya speleoarchaeology is the contextualization of cave use, which has been accomplished by identifying the nature and timing of ritual activities performed in caves through the analysis and interpretation of artifact assemblages. The current study focuses on a single, small rockshelter site, the Overlook Rockshelter (OVR), that was investigated as one component of a broad regional cave survey currently being conducted by the Central Belize Archaeological Survey project.

Increasingly, cave studies in the Maya area have taken the form of broad regional surveys that have sought to articulate data from a variety of subterranean sites into more traditional archaeological research designs, actively incorporating data from sites of different size, morphology, and proximity to other archaeological contexts (Awe, 1998; Bonor Villarejo, 1987; Brady et al., 1997; Hardy, 2009; Peterson, 2006; Prufer, 2002; Rissolo, 2003; Wrobel et al., 2009). In contrast to the generalized picture of ancient Maya cave use previously available, which was generally based on single sites, these regional approaches are designed to paint a holistic picture of the range of cave rituals practiced by specific groups living in a particular area. Furthermore, such studies can help illuminate broader patterns of cave use that are not necessarily restricted to rituals performed in a single locale. Such patterns would be invisible in cases where researchers treated cave contexts as isolated and bounded ritual contexts. Thus, the data from OVR can be compared to and contrasted with other related sites, providing contextualization for identified ritual behaviors. Furthermore, ethnographic analogy is often utilized as a means of linking artifact assemblages to specific types of rituals, as well as the nature of the ideological significance caves held within Maya belief systems (see Brady, 1989, and Brady and Prufer, 2005 for extensive reviews and examples). As an example, our discussion of OVR as a cave stems from ethnographic and ethnolinguistic studies suggesting that rockshelters were conceptualized and appropriated by Mesoamerican peoples as caves (see Risollo, 2005, p. 354 356). However, ethnographic analogy does not provide all the answers, and as Risollo (2005, p. 354) points out, "while semantic analyses among the modern Maya are important in steering the direction of research, it remains for archaeologists to document the palpable evidence of underground utilization in order to define boundaries of the ancient Maya concept of 'cave'."

\footnotetext{
${ }^{1}$ Department of Anthropology, Michigan State University, East Lansing, MI 48824, USA, wrobelg@msu.edu

${ }^{2}$ AR Consultants, Inc., Dallas, TX

${ }^{3}$ Department of Archaeology, University of Calgary, Alberta, Canada

${ }^{4}$ Department of Anthropology, Texas A\&M University, College Station, TX 778434352, USA

${ }^{5}$ Department of Sociology and Anthropology, University of Mississippi, Oxford, MS 38677-1848, USA
} 


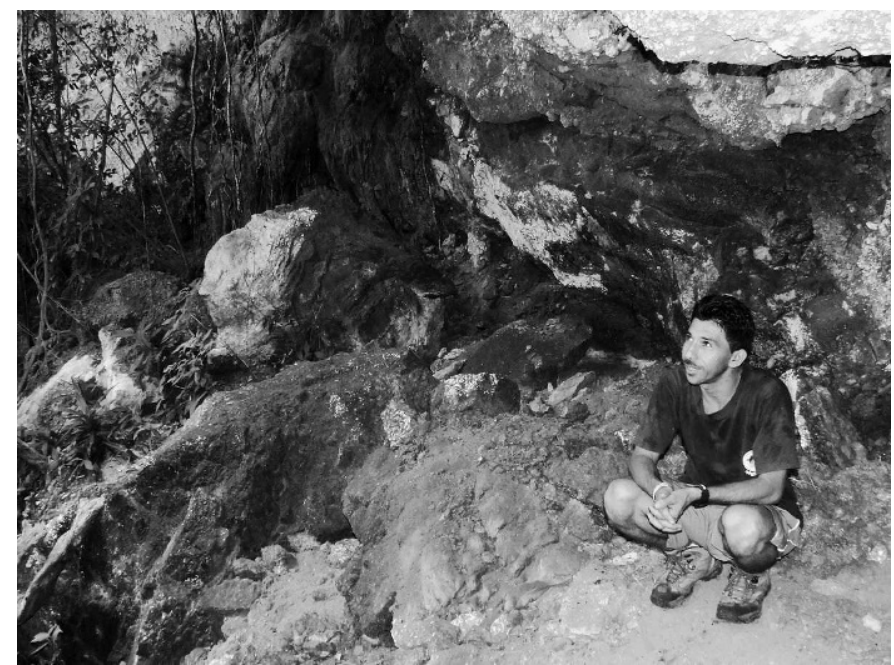

Figure 1. Elmer "Neko" Medrano at the Overlook Rockshelter. View toward the north.
Overlook Rockshelter was targeted for excavation in 2009 because it possessed a relatively unique combination of attributes not found at other sites in our survey. OVR is a small overhang with no associated dark zone and located on a sheer limestone cliff face hidden by vegetation high above the Caves Branch Valley (Fig. 1). Surface collection had revealed an assemblage consisting primarily of heavily fragmented ceramics. In particular, the unexpected presence of human remains at such a small and isolated site was intriguing; rockshelter burials have been noted at other nearby sites, such as Caves Branch Rockshelter (Glassman and Bonor, 2005; Wrobel et al., 2007), Sapodilla Rockshelter (Wrobel and Shelton, 2011), Actun Nak Beh (Halperin, 2005), and Uayazba Kab (Gibbs, 2000), but these sites possess generally larger activity areas with an associated dark-zone cave (Fig. 2). Furthermore, unlike the OVR, these other examples are easily accessible and seem to be directly associated with nearby settlement. Because of the small size of the activity areas and the fact that this site is not actively used for tourism, we decided to excavate the cultural features completely, collecting all artifacts. While taphonomic processes have likely played their part, we feel

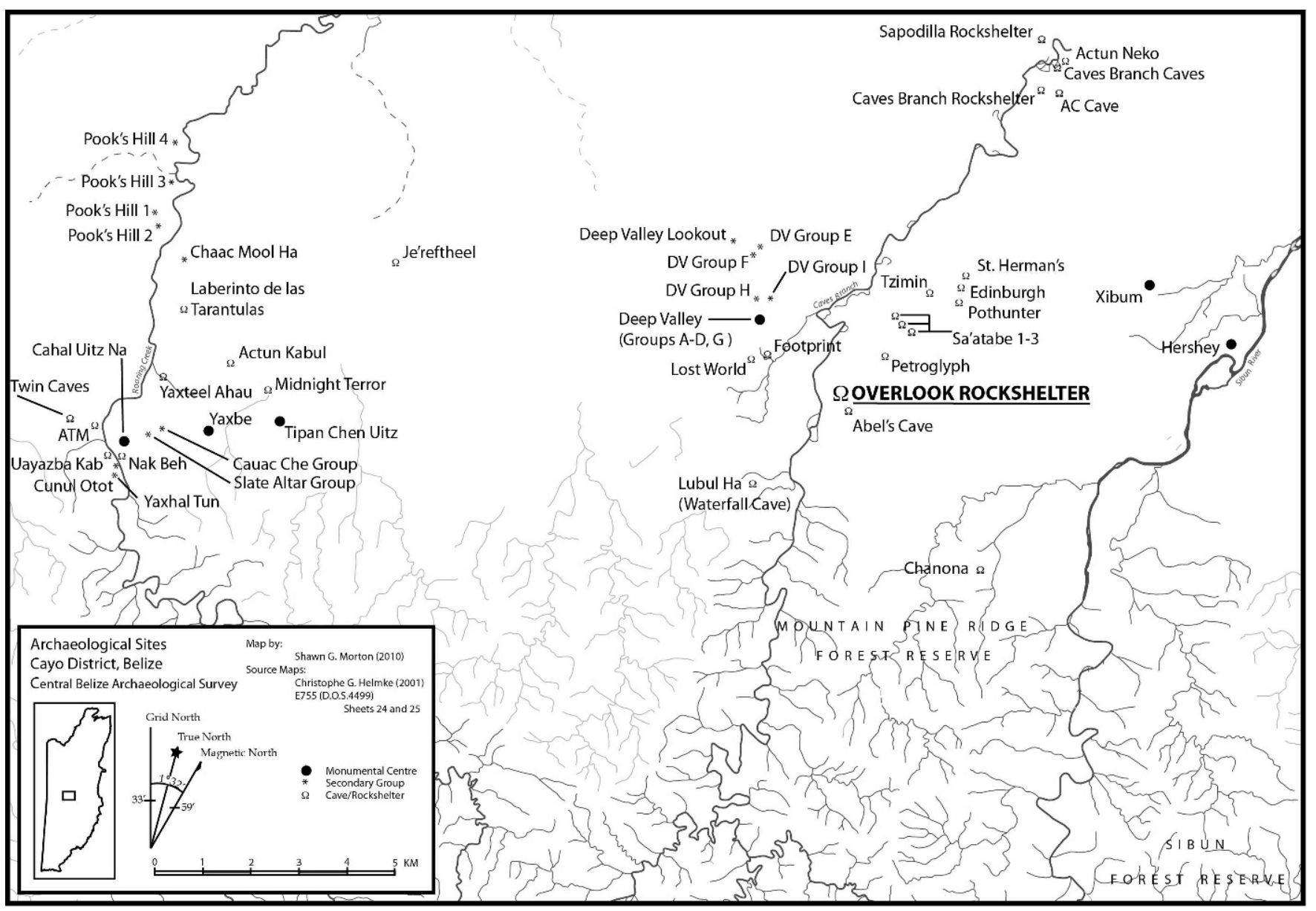

Figure 2. Map of study area, showing nearby sites. 


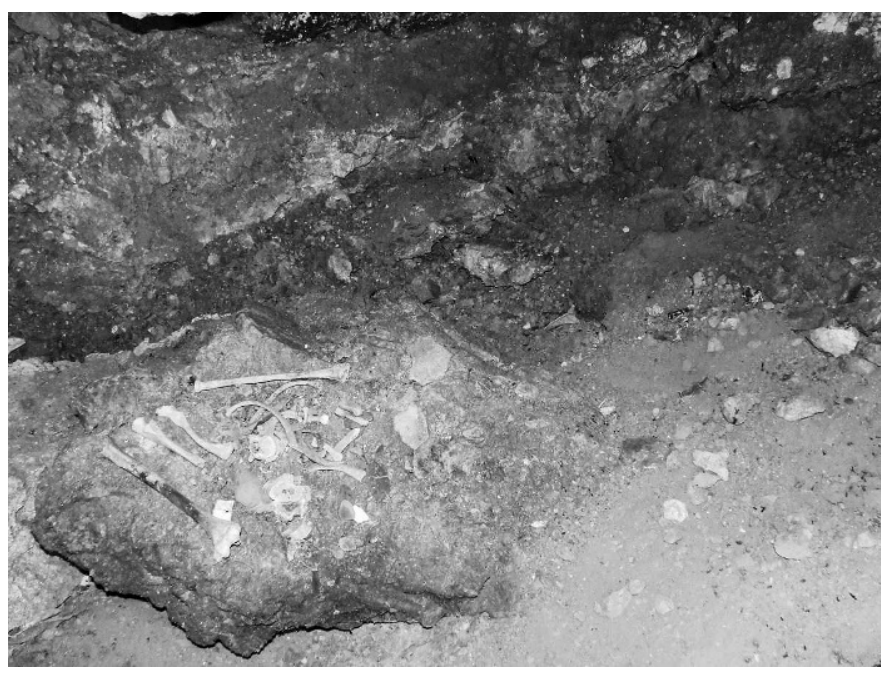

Figure 3. Area A, showing recently piled bones and artifacts to the left, and the area of disturbance to the right.

reasonably confident in stating that the vast majority of the artifacts deposited in the past remained in context. There are no previous attempts to collect and study a complete artifact assemblage from a rockshelter, and for this reason this study represents a unique and invaluable source of data with which to interpret the ritual activities performed at such sites.

\section{Description of the Site And the Excavations}

Members of the Belize Valley Archaeological Reconnaissance project and guides from Ian Anderson's Caves Branch Adventure Company and Jungle Lodge first reported Overlook Rockshelter after a brief reconnaissance in the summer of 2008. The ground surface is uneven, with only two discrete areas that contained scattered artifacts and human bone. In both areas, bones and sherds had been stacked (probably recently) on some of the loose stones on the surface (Fig. 3). Ceramic sherds accounted for most of the artifacts visible on the surface, though freshwater jute shells and several river cobbles were also noted. Typical of most other cave and rockshelter sites in the area, the jute had broken, or spirelopped, tips to facilitate consumption of the animal inside (see Halperin et al., 2003 for discussion of the ritual significance of jute among the Maya). The rest of the surface does not contain soil or any traces of human activity and is composed of flowstone and large boulders of breakdown from the cliff face above. The rockshelter is oriented roughly north to south, facing east with a spectacular view of the valley floor. By late afternoon the sun clears the overhanging roof and the entire rockshelter is exposed to direct sunlight. The wall of the OVR curves slightly outward toward the northernmost

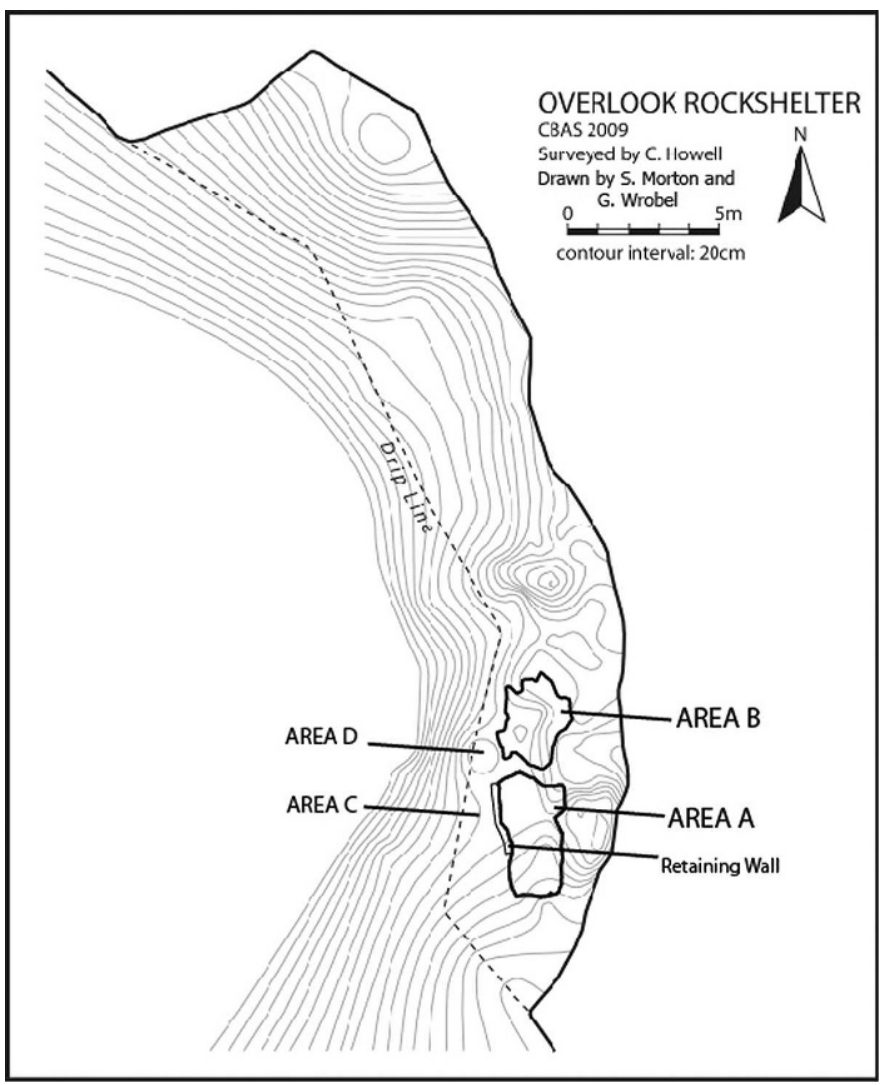

Figure 4. Topographic map of the Overlook Rockshelter.

end of the shelter. A short climb up the limestone wall of the elevated northern corner of the OVR reveals another small rockshelter; it has no artifacts visible on the surface.

Excavation units were set up in the only two areas with noticeable cultural material (Fig. 4). These areas were the only areas within the rockshelter that contained loose soil, while all other surfaces were composed either of solid or eroding limestone. Furthermore, the boundaries of both were naturally lined by large stones and thus were relatively easy to determine. The soil within these areas matched the matrix found in other rockshelters in the surrounding area-loose, dark, and composed mainly of limestone breakdown from the cliff walls (Hardy, 2009, p. 62). All of this loose soil from both areas comprised a matrix containing ceramic sherds, as well as a few other pieces of material cultural, that were mixed throughout it. The surface of these areas contained recent breakdown from the rockshelter ceiling in the form of several large rocks that were removed prior to excavation. All visible scattered or stacked artifacts and bones were collected as a single surface context. Based on prior experience with rockshelters, we did not anticipate finding clear stratigraphy, so arbitrary $20 \mathrm{~cm}$ levels were used.

Area A is located in the southernmost portion of the rockshelter and was defined by rock collapse (north and 
south), the natural cave wall (west), and a crudely constructed retaining wall (east). It measured $202 \mathrm{~cm}$ (EW) by $384 \mathrm{~cm}(\mathrm{~N}-\mathrm{S})$ at its largest. There was a narrow trench, initially hypothesized to be a small looter's pit, that upon further investigation turned out to be an area of natural collapse into a narrow fissure beneath the soil. Area B was the other main focus of excavation efforts. It measured $220 \mathrm{~cm}(\mathrm{E}-\mathrm{W})$ by $302 \mathrm{~cm}(\mathrm{~N}-\mathrm{S})$ at its largest and was separated from Area A by a loose pile of collapsed rock. Excavations within both areas, as expected, did not reveal any clear stratigraphy (i.e., the soil matrix was relatively uniform in color and artifact density throughout) and sterile soil was reached at a maximum depth of approximately $60 \mathrm{~cm}$ within most of both units. Artifacts found in the excavations from both areas included numerous pottery sherds, jute shells, and a few pieces of obsidian. Area A contained a small, drilled slate disk and a carved marine shell bead, as well as a higher concentration of human bone (Fig. 5). Area B contained a fish-net weight and a relatively higher concentration of jute shells.

A small flat area of ground that runs from the base of the eastern stone wall boundary of Area A to the edge of the rockshelter also contained a few artifacts, including small ceramic sherds and a few faunal remains. These remains were collected as Area $\mathrm{C}$. The shallow soil was very dense, and it is very likely that the cultural remains spilled over from Area A. Also, some of the soil and artifacts from Area B were washing out between the large boulders defining the eastern edge of the context. These artifacts, which included some of the largest sherds from the assemblage, were collected as Area D, though these clearly originate from Area B.

\section{Osteological Analysis}

The inventory of the skeletal remains shows that most bones likely come from a single incomplete individual, based on similar taphonomic characteristics, the generally consistent size and robusticity of elements, and in some cases corresponding articular surfaces of adjacent bones (in the left arm and the feet). However, the majority of the skeleton is absent, and the small size of the fissure in Area A is not sufficient to explain the missing elements. Most of the bones are complete and, apart from the ribs, no fragments were found. Where available, sex and age indicators consistently indicate that the primary individual is an older adult female. The age is based on the presence of osteophytes visible on the lumbar vertebra and on discrete patches of arthritis noted on the glenoid surface and on the pelvis around the auricular surface. In addition, the individual displays a pronounced preauricular sulcus and pubic pitting, which are typically interpreted as stress resulting from childbirth.

Each segment of the spinal column is represented by at least one vertebra. Few of these appear to be consecutive, however, and thus the vertebral bones included in the

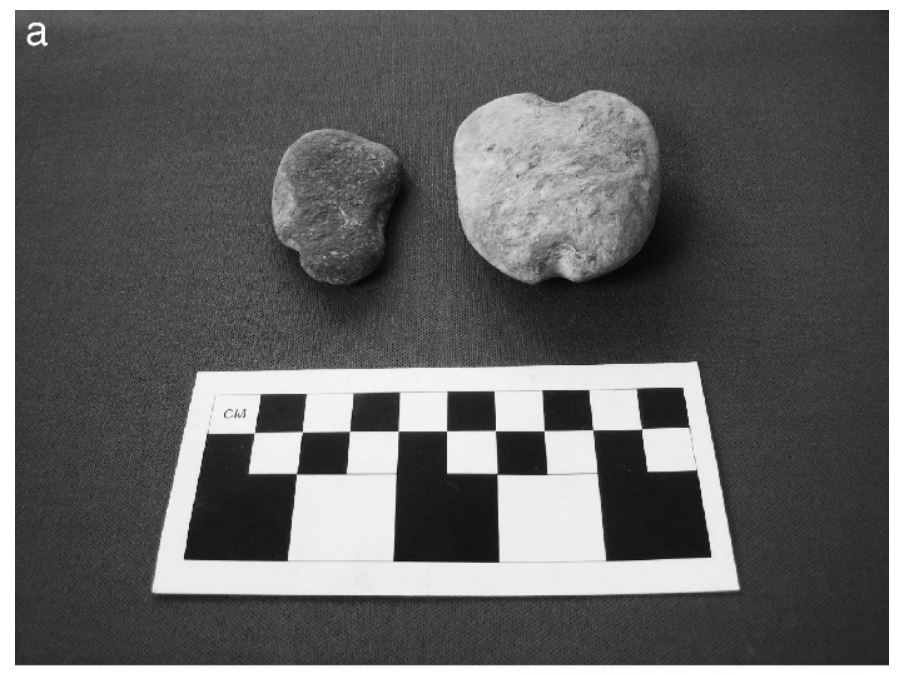

b

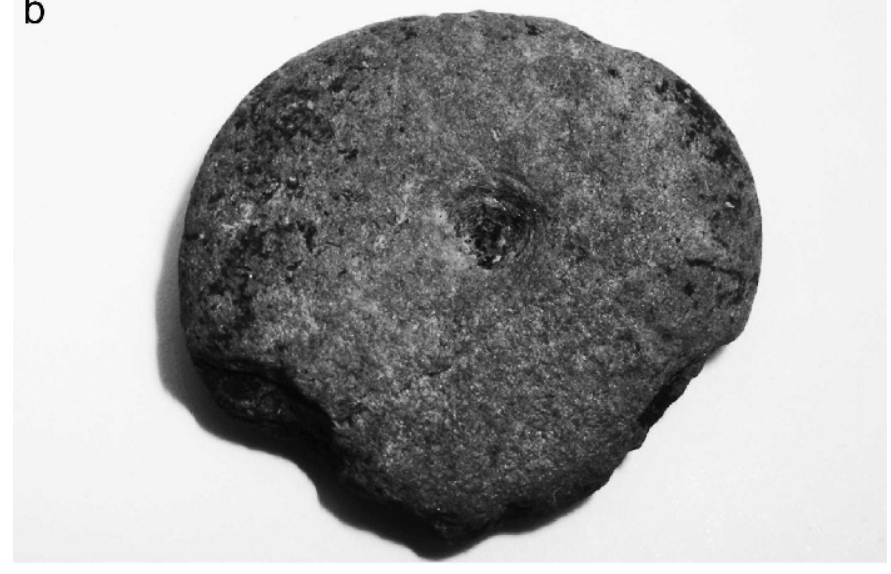

C

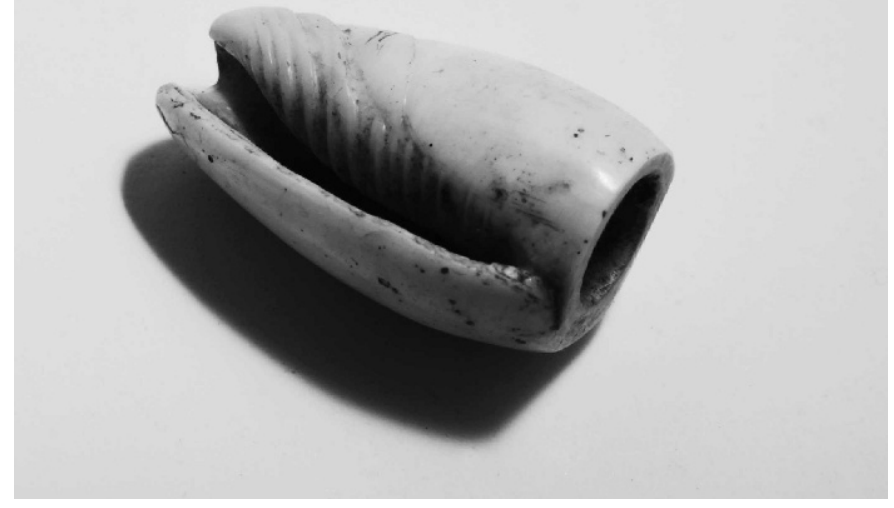

Figure 5. Photograph of (a) slate fragment and net weight, (b) drilled slate fragment, and (c) shell bead from Lots 4 and 5, Overlook Rockshelter, Belize.

assemblage were likely selected individually rather than as segments (i.e., upper or lower body). The pelvis includes small fragments of the sacrum and segments of the left os coxae, including the ischium, pubis, acetabulum, and a 
portion of the left auricular surface. Approximately half of the ribs were present, though many of these had fragmented. The most consistently represented portion of the skeleton is the left arm, which includes the clavicle, humerus, ulna, radius, and much of the scapula. The left hand is represented by all five metacarpals, as well as the lunate, capitate, and hamate. The right hand has only metacarpals 1, 3, and 4, though five phalanges were identified that may belong to either hand. Foot bones include several tarsals from each foot (left $=$ navicular, talus, and calcaneus; right $=$ navicular, talus, and $3 \mathrm{rd}$ cuneiform) and only a fragment of a single metatarsal. Toe phalanges present included all proximal phalanges except the first left, no middle phalanges, and only a single distal phalange of the right first toe. No fragments of the leg bones were present, though both patellas were found. An AMS analysis (Beta-279539; $1640 \pm 40 \mathrm{BP}$ ) of a rib gave a calibrated two-sigma range of $\mathrm{AD} 330-540$, placing the individual securely within the Early Classic (AD 300-600) period.

Within the bone assemblage are also at least a few random elements from other individuals, including an unfused coracoid process from a juvenile's scapula. Also, the only four teeth found at the site, all of which were permanent, represent at least two different individuals based on differences in attrition. An upper left first premolar had a nearly complete root, suggesting an approximate age around 10 to 12 years. A lower left first premolar had a complete root, but displayed a similar amount of wear, and thus could represent the same individual. The remaining two teeth, a lower right lateral incisor and canine, were from a slightly older individual and displayed minimal amounts of attrition and similarly polished surfaces. Since no cranial elements were found, and all teeth seem to come from relatively young individuals, it is likely that none belong to the primary individual. We have calculated a minimum number of three individuals on the basis of the different ages represented by the teeth and bones, though it is certainly conceivable that some of the teeth or smaller bone fragments belong to additional individuals.

\section{Ceramic Analysis}

Excavations revealed approximately 1700 ceramic sherds, which demonstrated diagnostic attributes spanning the Late Preclassic (300 BC to AD 250) through the Late Classic (AD 600-900) periods; identification was based on the type-variety method of Gifford, 1976. The relatively small assemblage contained a wide range of types within four wares: Uaxactun Unslipped, Peten Gloss, Pine Ridge Carbonate, and Paso Caballo Waxy Ware. The Late Preclassic diagnostic specimens were limited to two Sierra Red rim sherds and possibly one Sapote Striated: Unspecified (red rim) variety. Early Classic sherds included ring bases of unspecified types and one Actuncan Orange
Polychrome: Actuncan Variety rim sherd. In addition, a number of decorated body sherds appear to be of the Protoclassic-Early Classic Cocay Appliquéd type, which is also known as Tzimin Appliquéd (Reents, 1980, p. 168186, 60). The Late Classic is represented by several Dolphin Head Red: Dolphin Variety rim sherds, which date to the early facet Spanish Lookout phase. Over $86 \%$ of the sherds were unslipped, with $30 \%$ of these being striated. Less than $10 \%$ were slipped, and only three polychrome sherds were present. There were no apparent differences in the ceramics between the sub-assemblages from Areas A and B. Furthermore, comparisons within the units did not reveal expected temporal differences in the ceramics found in the upper and lower levels of the deposits. This has implications for the site's formation processes. Mixing of sherds throughout vertical levels was also noted at other nearby rockshelters (Hardy, 2009; Wrobel et al., 2007). At Caves Branch Rockshelter, mixing was explained by the constant intrusion of new burials. As this behavior is not evident at Overlook Rockshelter, it is possible that the depositional pattern observed is the result of extensive bioturbation in the rockshelter's unconsolidated matrix (see Haynes and Agogino, 1986). Alternative cultural hypotheses include that this depositional pattern reflects an as yet unidentified cultural process that would have acted to churn the matrix or that these sites may have been used over a relatively protracted period in the Late Classic, in which case deposits would include old sherds moved from other locations on the landscape. In reference to this second possibility, Joel Palka (personal communication, March 2012) has noted that among the modern Lacandon Maya at Mensabak, Chiapas, sherds and other ancient objects that are found in fields are thought to be associated with the past or with gods or ancestors and are picked up and redeposited within rockshelters. This possibility is especially intriguing because it would also explain the lack of stratigraphy in the deposits at OVR, and it thus deserves further consideration in future studies.

Overall, the broad time scale and the types of vessel forms represented at Overlook Rockshelter fit relatively well within established regional patterns for rockshelters and caves (Awe et al., 1998; Graham et al., 1980; Hardy, 2009; Helmke, 2009; Reents, 1980). As expected, OVR (like other rockshelters) does not show the full variety of ceramic forms often noted in dark-zone caves, which, in addition to utilitarian vessels, often include vases, shoeshaped ollas, censor drums, ocarinas, comales, and disks or lids (Helmke, 2009, p. 494-95; Reents, 1980). Similarly to both caves and other rockshelters, OVR's assemblage has a relatively large percentage of sherds from unslipped and striated jars (ollas) and bowls. The forms of the plainware vessels from which the sherds originate are consistent with those typically identified as utilitarian when they are found in household or other non-cave contexts. Unfortunately, we cannot make specific inferences about which of the many possible ritual or domestic activities these vessels 
were actually used in prior to their fragmentation and the subsequent deposition of their pieces. However, the consistency of OVR's assemblage does appear to be somewhat distinct from other nearby documented rockshelters that generally contain a very large percentage of the same plainwares, but also tend to include individual sherds from a much wider variety of specialized vessel forms, including polychrome dishes, column or pyriform vases, miniatures, ceramic spindle whorls, and net weights (Hardy, 2009). Additionally, other assemblages often contain a larger variety of decorated sherds from specialized vessels such as Terminal Classic model-carved sherds and Daylight-Darknight vessels (Hardy, 2009; Wrobel and Shelton, 2011). Thus, it appears that this aspect of depositional behavior typical of cave and rockshelter ritual was absent at OVR.

The ceramic analysis implies some specific depositional behaviors, which also can be used to inform reconstructions of ritual use of the rockshelter. Perhaps the most significant discovery during the analysis of the ceramics was that the assemblage contained very few refits between sherds, with no evidence for the presence of partial or complete vessels. Only 35 of the nearly 1700 sherds were rim sherds representing over 30 vessels with no refits. These vessels represent a variety of forms, including jars, dishes, and bowls. Despite the number of Peten Gloss body sherds, there were no rim sherds that refit to the incised Peten Gloss neck sherds in the assemblage. The appliqué decorations on the limited number of decorated body sherds are typically found around the circumference of Cocay Appliquéd jars, yet if there were whole vessels in the assemblage, there would have been a much larger number of decorated sherds. Based on the overall small size of the sherds, their eroded condition, and the lack of refits, it appears that the ceramics deposited at OVR were left as individual sherds instead of whole vessels.

In her regional rockshelter study of the Caves Branch River Valley, Hardy (2009) identified distinctly different depositional patterns of ceramics. For instance, the sixteen whole vessels found at the Caves Branch Rockshelter (CBR), all of which dated to around the Protoclassic period, appeared to have been interred intact with burials. However, the broader temporal diversity and variation in vessel types and the general lack of refits of the sherds found throughout the matrix at the CBR and the other rockshelters in the study suggested to Hardy $(2009$, p. 103) that they were instead deposited as fragments. Because these sites were only sampled using test-pits, the lack of refits in her sample could possibly be explained by ritual behavior in which complete vessels were smashed and then spread across an entire single site. However, the data from OVR suggest otherwise. In the neighboring Sibun River Valley and the Maya Mountains, deposition of complete vessels left whole or ritually killed/smashed and of scatters of individual sherds, have been recorded (Peterson, 2006, p. 57, 64, 126; Prufer, 2002). At Actun Toh in Quintana
Roo, Rissolo (2003, p. 47-54) notes that it appears as if ceramics were brought into the cave as sherds and were scattered along the surfaces so as to mark them as paths (see also Moyes, 2005, p. 281). Recent salvage operations at the Sapodilla Rockshelter found similar patterns to Caves Branch Rockshelter, with whole vessels likely associated with burials, while the surface and matrix were littered with seemingly random ceramic sherds (Wrobel and Shelton, 2011).

\section{Discussion}

As mentioned above, the rockshelter was excavated completely, and thus the analyses of the artifacts and bones are unique in that they are based on a nearly complete assemblage, assuming that only a small percentage of the assemblage washed out over the edge of the steep cliff face. The importance of this approach lies in being able to rule out the possibility that missing elements from the skeleton or from ceramic vessels were initially deposited at the site but are buried elsewhere in it. While looting may also account for some missing elements of the assemblage, we suspect this is minimal, given the general lack of surface disturbance. In our experience, artifacts worth removing found lying on the surface of a site generate at least enough enthusiasm by looters to dig small pits, none of which were evident at OVR.

Two other ritual behaviors that are often documented ethnographically may also be responsible for the specific composition of ceramics within the Overlook Rockshelter assemblage. The first relates to the collection of rituallycharged objects (Brown, 2000; Scott, 2009, p. 91), as well as relocation of objects as caches in other ritual locations (Brady, 1989, p. 109). In this case, it is conceivable that individuals visiting OVR removed ceramics from piles of complete smashed vessels as keepsakes or for use in rituals performed elsewhere. The second ritual behavior is sweeping, which has been documented extensively in ethnographic contexts (Tozzer, 1941, p. 151-2; Vogt, 1976, p. 99; Brown and Emery, 2008, p. 317; Scott, 2009, p. 97) and has been hypothesized in a number of archaeological settings at both cave (Halperin, 2005; Prufer, 2002, p. 620) and surface sites (Coggins, 1987; Glassman et al., 1995, p. 60; Mathews and Garber, 2004, p. 52-53). Indeed, it is possible that the deposits at OVR may have accumulated as the result of sweeping clean a nearby activity area. If the ritual area requiring sweeping was located within OVR, it is also possible that the majority of ceramics initially deposited there were swept over the edge of the cliff and thus not recovered. While these remain possibilities, we suggest that they are unlikely, since both of these processes would result in a rather random assortment of ceramic sherds, and among the 1700 , we would expect that if each began as a whole vessel that at least some of those vessels would be represented by more than two pieces. Careful examination of the 
assemblage demonstrated through comparisons of variables like thickness, color, shape, decorations, inclusions (temper), and form that almost none of the pieces could belong to the same vessel. It seems unlikely that postdepositional collection of objects or sweeping would result in such a consistent pattern. Furthermore, periodic cleaning over an extended period of time, presumably at the initiation of a new rite, has been demonstrated elsewhere to produce a distinctive distributional pattern (Helmke et al., in press). This pattern is characterized by marked disparity in sherd density between activity areas and the peripheral areas of secondary deposition that such "sweeping" produces. No such pattern was observed at OVR. Thus, we are convinced that this assemblage represents a non-random assortment of sherds, and that individual vessels are only represented by one or two sherds, which is more consistent with the hypothesis that sherds were deposited at OVR individually.

The single partial secondary burial found at Overlook Rockshelter is unusual, but does have some correlates that may help to explain its significance. For instance, the three burials documented at Actun Nak Beh are also thought to be secondary partial burials. Halperin (2005) suggests that they may be the remains of elites who were incorporated into a specific type of cave ritual intended to legitimize authority and power of their relatives. Unlike OVR, however, the rockshelter entrance of Actun Nak Beh likely would have served as an area for public ritual, because it is a flat open space, it is directly connected to the monumental center of Cahal Uitz $\mathrm{Na}$ by a sacbe, and there is a small and restrictive dark zone that could have been used for private ceremonies. Furthermore, the OVR artifact assemblage consisted primarily of dense deposits of individual ceramic sherds, while Actun Nak Beh had very few sherds, perhaps as a result of ritual sweeping or periodic looting (Halperin, 2005, p. 80). So, while the form of the burials at Actun Nak Beh (i.e., secondary and partial) is similar to that at OVR, the contexts at the two sites are quite different, especially in regard to the relative isolation and difficult access of OVR, likely suggesting that the rituals performed at the two sites were distinctive.

A recent report on a solitary walled burial from Actun Bats'ub in southern Belize also shows some basic correlates with OVR, as well as a similar Early Classic date (Prufer and Dunham, 2009). Based on its isolated location and the likely postmortem manipulation of skeletal elements, the authors argue that the artifacts within Actun Bats'ub reflect a single specialized ritual specific to the individual based on the importance of his or her social role as a shaman. While the solitary nature of the OVR burial may also be argued to imply individualized treatment, the case for the Bats'ub burial is based on many contextual aspects that are not evident in the OVR interment. Bats'ub is a disturbed primary burial, it contains elaborate grave goods, and it is sealed within a dark-zone environment. In other words, the Bats'ub burial clearly parallels the reverential mortuary behavior characteristic of tombs, while the scattered and almost random bones of the OVR burial are treated in a way similar to the rest of the artifact assemblage within the general matrix. Furthermore, unlike at OVR, the diagnostic artifacts and radiocarbon dates from the Actun Bats'ub are all temporally homogenous, supporting the argument that this assemblage represents a single, though possibly protracted, ritual event.

The inventory and analysis of the remains at OVR provides some clues for deciphering the mortuary pathway leading to the interment. While the left arm is relatively complete, the almost random assortment of other elements, such as non-continuous elements of the spinal column and feet, for instance, and the complete lack of cut marks rules out peri-mortem mutilation of the body as an explanation for its incomplete state. Clearly, elements of the initial primary burial were removed after decomposition. Furthermore, while the presence or absence of some elements appears random (e.g., carpals), the suspiciously complete absence of leg long bones and the skull seems deliberate. (See Tiesler, 2004 for a discussion of natural and cultural influences on decomposition leading to differential preservation and representation of bones in Maya burials.) What is less clear is whether the elements of the OVR interment were moved to the rockshelter as a secondary burial, or whether the OVR was the site of the primary burial and the missing elements were subsequently removed. (See Fitzsimmons, 1998 for a description of prolonged mortuary practices among the Classic period Maya elite.) The complete lack of articulation supports the former hypothesis, while the presence of many of the smallest bones would tentatively support the latter. (See Prufer, 2002, p. 613, who discusses how assemblages can be affected by the behavior of ritual specialists, who pick up previously discarded objects for reuse in ceremonies.) However, the extra bones (teeth and infant clavicle) certainly must have been moved from elsewhere as individual elements, or one would expect to have found more elements of those individuals.

The nature of the artifact assemblage at Overlook Rockshelter may offer the best analogy for explaining the presence of the scattered bones of a partial skeleton. As noted, few of the sherds could be fitted together, suggesting that almost all came from different vessels. Furthermore, the presence of diagnostic forms from a span of nearly a millennium is certainly curious, since it may imply repeated and continuous use. While this pattern has been documented at a number of sites like the larger rockshelters and caves in the region (Hardy, 2009), it is surprising to find such consistent devotion to such a small, hard-to-reach, and generally unimpressive site as the OVR. It may be, however, that the single cave was not the focus of the ritual. Several researchers have argued that sites and even specific areas within sites were sometimes seen as connected parts within a ritual landscape and formed a series of way points along a ritual circuit (Garza et al., 2001, p. 22; 
Kenward, 2005; Moyes, 2005; Peterson, 2006, p. 120; Prufer, 2002, p. 639; see Adams and Brady, 2005 for an ethnographic discussion of ritual circuits). Ethnographically, this behavior is common to near ubiquitous and can be seen as an act in rituals of the hunt (Brown, 2005), of the house, of the field, and of the healing of the sick (Vogt, 1976 , p. 9-10, 54-55, 75), as well as in rituals of sociopolitical investment (Tedlock, 1982; see also Freidel et al., 1993, p. 419) and boundary maintenance (Tozzer, 1941; Vogt, 1969, p. 391). At each of these sites, individuals would leave a small offering.

In the ethnographic record, offerings are typically composed of what would be considered whole objects in a material sense. That is, ritualists deposit whole and intact arrangements of candles, plants, and other paraphernalia (see Tedlock, 1982; Vogt, 1976, p. 9-10, 54, 55). In our archaeological hypothesis, the difference is thus striking as we propose that the lack of an entire vessel in our assemblage may suggest that its individual pieces were dispersed across the landscape instead of being deposited together. However, while the material signature of the assemblage varies from our ethnographic model, it remains conceptually analogous: The ritual functions because offerings and locations are inexorably bound as one object open to manipulation (as in the Zinacanteco healing ritual described by Vogt, 1976, p. 9-10); in this way, the ritual is no less than the sum of its parts, and individual offerings are but fragments of this greater whole.

The paucity of rim sherds and the absence of larger sherds and partial vessels, as well as the rather mundane nature of most of the non-ceramic offerings, may reflect the small and marginal nature of the site compared to others on the circuit. If this scenario is accurate, the incomplete skeleton may represent an analogous situation in which the parts of the individual were also similarly dispersed. The largest and most distinctive bones of the primary individual - the leg bones and the cranium-may have been reserved for another more meaningful or significant location along the circuit. In other contexts, crania and longbones are often missing from elite burials, likely as a result of removal for use in veneration rituals (McAnany, 1995, p. 60-63). Finally, the Early Classic date of the bones falls securely between the earliest $(\sim \mathrm{AD} 1)$ and latest $(\sim \mathrm{AD} 800)$ ceramic dates. While this suggests that the interment likely does not represent a dedication ritual, the secondary nature of the burial leaves open the possibility that it was placed as part of a termination ritual despite the nearly 400 year interval (see Kunen et al., 2002).

\section{Conclusions}

The Overlook Rockshelter was excavated completely, resulting in the collection of a complete artifact assemblage. An Early Classic partial secondary burial of an adult female had been placed within the rockshelter, and was found scattered within the matrix. The artifact assemblage was generally typical of those from other rockshelters excavated in the area. Diagnostic ceramics showed a variety of forms similar to those reported in other cave contexts and also showed a range of dates spanning the Late Preclassic through Late Classic periods, which were mixed throughout all levels of the matrix. The lack of fits between the sherds showed that no whole vessels had been placed in the rockshelter, though it is certainly possible that looters removed whole vessels left on the surface. However, the general nature of the deposit suggests that the assemblage was created over a long period of time through the repeated deposition of single sherds, and occasionally other small, common, and inexpensive (though perhaps symbolically meaningful) objects, such as river cobbles, small used obsidian blade fragments, and jute shells. The documentation of the complete artifact assemblage at OVR has important implications for the interpretation of other cave contexts. Most cave sites contain ubiquitous single sherds in isolation or within clusters that are often hypothesized to be the remnants of complete smashed vessels whose fragments were subsequently moved by water or human activity. Instead, sites like these may represent part of a ritual circuit composed of many such sites, where an individual leaves small offerings at each. Similarly, this pattern may explain the incompleteness of the skeleton, which, like the vessels, could have been spread across the landscape. Future research focused on answering questions related to the nature of such deposits would benefit from detailed comparisons of assemblages at multiple sites across the landscape.

\section{ACKNOWLEDGEMENTS}

We would like to thank the following individuals and institutions for their support and assistance: Jaime Awe, John Morris, Rafael Guerra, and the Belize Institute of Archaeology; David Hayles, Ian Anderson, and all the staff at the Caves Branch Adventure Lodge; the Belize Archaeological Research and Education Foundation; the University of Mississippi's Barksdale Honors College and Department of Sociology and Anthropology; the many students participating on the 2009 CBAS summer fieldschool; Christophe Helmke, Jessica Hardy Haley, Cameron Howell, Leah Jaworskyj, Bruce Minkin, and Alex Minkin who also provided the Figure 5 photos. This manuscript was strengthened considerably by comments and suggestions from James Brady, Dominique Rissolo, Joel Palka, and an anonymous reviewer-many thanks to them.

\section{References Cited}

Adams, A.E., and Brady, J.E., 2005, Ethnographic notes on Maya Q'eqchi' cave rites: Implications for archaeological interpretation, in Brady, J.E., and Prufer, K.M., eds., In the Maw of the Earth Monster: Mesoamerican Ritual Cave Use: Austin, University of Texas Press, p. $301-327$. 
Awe, J.J., 1998, Western Belize Regional Cave Project: Objectives, context, and problem orientation, in Awe, J.J. The Western Belize Regional Cave Project, a Report of the 1997 Field Season: Durham, University of New Hampshire, Department of Anthropology Occasional Paper No.1, p. 1-22.

Awe, J.J., Helmke, C.G.B., and Griffith, C.S., 1998, Archaeological reconnaissance in the Roaring Creek Valley: Caves, rockshelters, and settlement architecture, in Awe, J.J., ed., The Western Belize Regional Cave Project, a Report of the 1997 Field Season: Durham, University of New Hampshire, Department of Anthropology Occasional Paper No.1, p. 223-244.

Bassie-Sweet, K., 1996, At the Edge of the World: Caves and Late Classic Maya World View: Norman, University of Oklahoma Press, 245 p.

Bonor Villarejo, J.L., 1987, Exploraciones en las grutas de Calcehtok y Oxkintok, Yucatán, Mexicó: Mayab, v. 3, p. 24-32.

Brady, J.E., 1989, An investigation of Maya ritual cave-use with special reference to Naj Tunich, Peten, Guatemala [Ph.D. thesis]: Los Angeles, University of California, $478 \mathrm{p}$.

Brady, J.E., and Prufer, K.M., eds., 2005, In the Maw of the Earth Monster: Mesoamerican Ritual Cave Use: Austin, University of Texas Press, $438 \mathrm{p}$.

Brady, J.E., Scott, A., Cobb, A., Rodas, I., Fogarty, J., and Urquizú Sánchez, M., 1997, Glimpses of the dark side of the Petexbatun project: The Petexbatun regional cave survey: Ancient Mesoamerica, v. 8, p. 353-364. doi:10.1017/S0956536100001784.

Brown, L.A., 2000, From discarded to divination: Demarcating the sacred through the collection and curation of discarded objects: Latin American Antiquity, v. 11, no. 4, p. 319-333.

Brown, L.A., 2005, Planting the bones: Hunting ceremonialism at contemporary and nineteenth-century shrines in the Guatemalan Highlands: Latin American Antiquity, v. 16, no. 2, p. 131-146.

Brown, L.A., and Emery, K.F., 2008, Negotiations with the animate forest: Hunting shrines in the Guatemalan Highlands: Journal of Archaeological Method and Theory, v. 15, p. 300-337. doi:10.1007/ s10816-008-9055-7.

Coggins, C., 1987, New fire at Chichen Itza, in Memorias del primer coloquio internacional de Mayistas, 5-10 Agosto, 1985: Mexico, Universidad Nacional Autónoma de México, p. 427-484.

Fitzsimmons, J.L., 1998, Classic Maya mortuary anniversaries at Piedras Negras, Guatemala: Ancient Mesoamerica, v. 9, no. 2, p. 271-278. doi:10.1017/S095653610000198X.

Freidel, D., Schele, L., and Parker, J., 1993, Maya Cosmos: Three Thousand Years on the Shaman's Path: New York, William Morrow, 544 p.

Garza, S., Brady, J.E., and Christensen, C., 2001, Balam Na Cave 4: Implications for understanding Preclassic cave mortuary practices: California Anthropologist, v. 28, no. 1, p. 15-21.

Gibbs, S.A., 2000, An interpretation of the significance of human remains from the caves of the southern Maya lowlands [M.A. thesis]: Peterborough, Trent University, $202 \mathrm{p}$.

Gifford, J.C., 1976, Prehistoric Pottery Analysis and the Ceramics of Barton Ramie in the Belize Valley: Cambridge, Harvard University, Peabody Museum Memoirs no. 18, 360 p.

Glassman, D.M., and Bonor Villarejo, J.L., 2005, Mortuary practices of the prehistoric Maya from Caves Branch Rockshelter, Belize, in Prufer, K.M., and Brady, J.E., eds., Stone Houses and Earth Lords: Maya Religion in the Cave Context: Boulder, University Press of Colorado, p. 285-296.

Glassman, D.M., Conlon, J.M., and Garber, J.F., 1995, Survey and initial excavations at Floral Park, in The Belize Valley Archaeology Project: Results of the 1994 field season: Ms. on file, Institute of Archaeology, Belmopan, Belize.

Graham, E., McNatt, L., and Gutchen, M.A., 1980, Excavations at Footprint Cave, Caves Branch, Belize: Journal of Field Archaeology, v. 7 , no. 2, p. 153-172. doi:10.1179/009346980791505518.

Halperin, C.T., 2005, Social power and sacred space at Actun Nak Beh, in Prufer, K.M., and Brady, J.E., eds., Stone Houses and Earth Lords: Maya Religion in the Cave Context: Boulder, University Press of Colorado, p. 71-90.

Halperin, C.T., Garza, S., Prufer, K.M., and Brady, J.E., 2003, Caves and ancient Maya ritual use of jute: Latin American Antiquity, v. 14, p. 207-219.

Hardy, J.L., 2009, Understanding functional and symbolic variation in rockshelters of the Caves Branch River Valley of western Belize,
Central America [M.A. thesis]: Oxford, University of Mississippi, $172 \mathrm{p}$.

Haynes, C.V., Jr., and Agogino, G.A., 1986, Geochronology of Sandia Cave: Washington, Smithsonian Institution Press, Smithsonian Contributions to Anthropology no. 32, 39 p.

Helmke, C.G.B., 2009, Ancient Maya cave usage as attested in the glyphic corpus of the Maya lowlands and the caves of the Roaring Creek Valley, Belize [Ph.D. thesis]: London, University College, 701 p.

Helmke, C., Awe, J.J., Morton, S.G., and Iannone, G., The archaeology and epigraphy of the Cuychen Vase, Macal Valley, Belize: Maya Archaeology, v. 3 [in press].

Kenward, A., 2005, Showing the way: The function of three small caves in the Sibun-Manatee Karst, in Prufer, K.M., and Brady, J.E., eds., Stone Houses and Earth Lords: Maya Religion in the Cave Context: Boulder, University Press of Colorado, p. 249-259.

Kunen, J.L., Galindo, M.J., and Chase, E., 2002, Pits and bones: Identifying Maya ritual behavior in the archaeological record: Ancient Mesoamerica, v. 13, p. 197-211. doi:10.1017/S0956536102132032.

Mathews, J.P., and Garber, J.F., 2004, Models of cosmic order: Physical expression of sacred space among the ancient Maya: Ancient Mesoamerica, v. 15, p. 49-59. doi:10.1017/S0956536104151031.

McAnany, P.A., 1995, Living with the Ancestors: Kinship and Kingship in Ancient Maya Society: Austin, University of Texas Press, 229 p.

Moyes, H., 2005, Cluster concentrations, boundary markers, and ritual pathways: A GIS analysis of artifact cluster patterns at Actun Tunichil Muknal, Belize, in Brady, J.E., and Prufer, K.M., eds., In the Maw of the Earth Monster: Mesoamerican Ritual Cave Use: Austin, University of Texas Press, p. 269-300.

Peterson, P., 2006, Ancient Maya Ritual Cave Use in the Sibun Valley, Belize: Austin, Association for Mexican Cave Studies, Bulletin 16, $148 \mathrm{p}$.

Prufer, K.M., 2002, Communities, caves, and ritual specialists: A study of sacred spaces in the Maya Mountains of southern Belize [Ph.D. thesis]: Carbondale, Southern Illinois University, $755 \mathrm{p}$.

Prufer, K.M., and Brady, J.E., 2005, Introduction: Religion and the role of caves in Lowland Maya archaeology, in Prufer, K.M., and Brady, J.E., eds., Stone Houses and Earth Lords: Maya Religion in the Cave Context: Boulder, University Press of Colorado, p. 1-24.

Prufer, K.M., and Dunham, P.S., 2009, A shaman's burial from an Early Classic cave in the Maya Mountains of Belize, Central America: World Archaeology, v. 41, no. 2, p. 295-320. doi:10.1080/00438240902844236.

Reents, D., 1980, The prehistoric pottery from Petroglyph Cave, Caves Branch Valley, El Cayo District, Belize, Central America [M.A. thesis]: Austin, University of Texas, 323 p.

Rissolo, D., 2003, Ancient Maya Cave Use in the Yalahau Region, Northern Quintana Roo, Mexico: Austin, Association for Mexican Cave Studies, Bulletin 12, $151 \mathrm{p}$.

Rissolo, D., 2005, Beneath the Yalahau: Emerging patterns of ancient Maya ritual cave use from northern Quintana Roo, Mexico, in Brady, J.E., and Prufer, K.M., eds., In the Maw of the Earth Monster: Mesoamerican Ritual Cave Use: Austin, University of Texas Press, p. $342-372$.

Scott, A.M., 2009, Communicating with the sacred earthscape: An ethnoarchaeological investigation of Kaqchikel Maya ceremonies in highland Guatemala [Ph.D. thesis]: Austin, University of Texas, $227 \mathrm{p}$.

Tedlock, B., 1982, Time and the Highland Maya: Albuquerque, University of New Mexico Press, 309 p.

Tiesler, V., 2004, Maya mortuary treatments of the elite: An osteotaphonomic perspective, in Graña Behrens, D., Grube, N., Prager, C.M., Sachse, F., Teufel, S., and Wagner, E., eds., Continuity and Change. Maya Religious Practices in Temporal Perspective: 5th European Maya Conference, University of Bonn, December 2000: Munich, Verlag Anton Saurwein, Acta Mesoamericana 14, p. $143-156$.

Tozzer, A.M., 1941, Landa's Relación de las Cosas de Yucatán: A translation: Cambridge, Harvard University, Papers of the Peabody Museum of Archaeology and Ethnology, vol. 18, 394 p.

Vogt, E.Z., 1969, Zinacantan: A Maya Community in the Highlands of Chiapas: Cambridge, Belknap Press of Harvard University, $733 \mathrm{p}$.

Vogt, E.Z., 1976, Tortillas for the Gods: A Symbolic Analysis of Zinacanteco Rituals: Cambridge, Harvard University Press, 234 p. 
Vogt, E.Z., and Stuart, D., 2005, Some notes on ritual caves among the ancient and modern Maya, in Brady, J.E., and Prufer, K.M., eds., In the Maw of the Earth Monster: Mesoamerican Ritual Cave Use: Austin, University of Texas Press, p. 155-185.

Wrobel, G.D., Jordan, J., and Hardy, J., 2009, Social and political transformations in the Caves Branch River Valley: Evidence from natural and constructed ritual environments: Research Reports in Belizean Archaeology, v. 6, p. 199-207.
Wrobel, G.D., and Shelton, R., 2011, Preliminary salvage operations at Sapodilla Rockshelter, in Andres, C.R., and Wrobel, G.D., eds., Report on the Caves Branch Archaeological Survey Project, Summer 2010 Field Season: Oxford, Mississippi, Belize Archaeological Research and Education Foundation Occasional Report \#2, p. 18-40.

Wrobel, G.D., Tyler, J., and Hardy, J., 2007, Rockshelter excavations in the Caves Branch River Valley: Research Reports in Belizean Archaeology, v. 4, p. 187-196. 